DOI https://doi.org/10.18551/rjoas.2017-01.09

\title{
THE IMPACT OF E-WOM ON DESTINATION IMAGE, ATTITUDE TOWARD DESTINATION AND TRAVEL INTENTION
}

\author{
Ramdan Muhamad Rizky*, Rahardjo Kusdi, Abdillah Yusri \\ Faculty of Administrative Science, University of Brawijaya, Indonesia \\ ${ }^{*}$ E-mail: rizky.ramdan92@gmail.com
}

\begin{abstract}
Electronic word of mouth (e-WOM) is a new development of word of mouth by using social media platform to interact in the internet. Current studies only examine the model on its own basis by using theory planned behavior (TPB). Based on this idea, this research is trying to examine the model of e-WOM, Destination Image, Attitude Toward Destination together to reveal which factor that give the greater effects against travel intention both direct effect, indirect effects and total effects. The study was using the Generalized Structured Component Analysis (GSCA) methodology to test the model. The research object was the @explore_batu in Instagram as many as 167 online respondents against tourist destination in Batu City. Results show that: (1) e-WOM positively influences Destination Image; (2) eWOM positively influences Attitude Toward Destination; (3) e-WOM positively influences Travel Intention; (4) Destination Image influences Travel Intention and (5) Attitude Towards Destination influences Travel Intention. The e-WOM is a crucial part of this research because has a greater effect on Destination Image and Travel Intention. Implication, limitation, discussion and future research direction are discussed at the end of the paper.
\end{abstract}

\section{KEY WORDS}

e-WOM, destination image, attitude toward destination, travel intention.

The internet growth has seen and adoption of new ways of consumer trends. WOM has involved in an entirely new form of communication by adopting internet technology. This is termed as electronic word of mouth (e-WOM) communication, e-WOM can be defined as any positive or negative statement made by potential, actual, or former customers about a product or company which is made available to a multitude of the people via the internet (Hennig-Thurau et al, 2004). McKinsey and Company published a report on e-WOM and stated that the scope of e-WOM in emerging markets is relatively higher than traditional advertising.

In 2012, growth in data usage is generally driven by the growth of mobile phone owners, especially smartphones. A survey Netizen Indonesia 2012 conducted by Markplus Insight showed some interesting findings. One of the most important positive growth of data usage in Indonesia, about $40 \%$ of Internet users in Indonesia access the Internet more than 3 hours per day can be classified as Netizen. The community such as youth, women and netizen more often use the time to explore the internet to share pictures, songs, data and stories to friends (Kertajaya and Nirwandar, 2013). As shown in table 1.1 it is amazing to note that netizen population has grown exponentially from 4,160,000 people in 2010 to $61,080,000$ people in 2012 , the data has shown total internet users penetration are very high (Kertajaya and Nirwandar, 2013). The growth of internet users makes people look for information in advance about tourism services, such as accommodation, entertainment available, the typical food of the area and the circumstances surrounding community locations in tourism destinations. Services providers are also increasingly active and begin to provide a reliable platform for tourist information.

Although e-WOM is more effective than traditional ads, recommendation messages from individuals who formatted text based clearly presents obstacles and difficulties in assessing familiarity and reliability of the source of the message (Chatterjee, 2001). Based on it, online customers will have a dilemma and doubt in trusting the messages that are sent from another user. Marketers need to understand the credibility the message sources and 
the message appeals to understand the effect of e-WOM. The recommendation or some review that have been given to another customer in shared reviews or community platform undoubtedly able to influence the travel intention of customers. Message sources credibility has a lot of effects on whether or not the customers believe the message (Wu and Wang, 2011).

Table 1 - Growth of Internet Users in Indonesia

\begin{tabular}{|l|c|c|c|}
\hline \multicolumn{1}{|c|}{ Classification } & 2010 & 2011 & 2012 \\
\hline Urban Population & \multicolumn{3}{c|}{ Mlns } \\
\hline Urban Family & 121.16 & 123.24 & 123.57 \\
\hline Urban Netizen Population & 37.56 & 50.53 & 56.38 \\
\hline Netizen Population & 42.16 & 55.23 & 61.08 \\
\hline Total Internet User Penetration & $17 \%$ & $22.4 \%$ & $23.5 \%$ \\
\hline
\end{tabular}

This research will be conducted in explore_batu as online travel reviews on Instagram who give reviews and share tourist destination in Batu City. Explore_batu attract to research because Batu City has more than 20 tourists destinations. Batu City has beautiful panorama and potential to attract tourist to visit and enjoy mountains area. At the 19th century Batu City has started to grow as a tourist destination, especially for Hollander, so they started to establish rest area and villa for staying at Batu City (Hudjiono, 2012). Today, Batu City is one of the favorite places for a holiday. Enjoying diverse recreational places such as Jawa Timur Park, Selecta, Cangar, Coban Rondo Waterfall, Paralayang, Songgoriti, Museum of Transportation, Eco Green Park, Batu Night Spectacular, Cangar and Predator Fun Park. The local government and investors have successfully developed the tourism industry in this city, as reflected by the break of the tourist who visit Batu city amount 3.29 million in 2014 (BPS Kota Batu, 2014). Table 2 shows total Tourist Arrival in Batu City as follow,

Table 2 - Tourist Arrival in Batu City

\begin{tabular}{|c|c|}
\hline Year & Tourist Arrival \\
\hline 2008 & $1,180,042$ \\
\hline 2009 & $1,906,170$ \\
\hline 2010 & $2,084,487$ \\
\hline 2011 & $2,030,194$ \\
\hline 2012 & $2,547,885$ \\
\hline 2013 & $3,292,298$ \\
\hline
\end{tabular}

\section{THEORETICAL REVIEW}

Consumer Behavior in Tourism. The mostly travel providers' considered experience of services quality (Sorensen, 2013), mainly intangible that quality is difficult to be evaluated prior consumption (Zeithaml et al, 2013). Consumer behavior determines high customers' involvement in buying decision practices and a consequent high risk perception that usually generates a longer and more complex consumer behavior process (Laroche et al, 1996). Moreover, purchase of travel services is increasingly taking place in the online environment (Vigilia, 2014).

Table 3 - The Stages of Consumers' Behavior and Travel Planning Process

\begin{tabular}{|l|c|}
\hline \multicolumn{1}{|c|}{ Consumer Behavior Stages } & Three Phase Travel Planning Process \\
\cline { 1 - 1 } Need Recognition & \\
\cline { 1 - 1 } Information Search & Pre-Trip Phase (anticipatory) \\
\hline Evaluation of Alternatives & \\
\hline Purchase Decision & During Trip Phase (experiental) \\
\hline Post purchase (Post Decision Behavior) & Post Trip Phase \\
\hline Ponsumption & \\
\hline
\end{tabular}


In order to analyze how consumers buy tourism services, a brief review of the theories regarding purchasing process is presented in traveler buying process. Based on to the decision making studies, the traveler buying process consists of five stages, need recognition, information search evaluation of alternatives, purchase decision, and post purchase behavior (Kotler et al, 2010; Zeithaml et al, 2012). A perspective of analysis of the tourists' planning process (travel planning theory) suggests a temporal perspective based on a process generally composed by three phases, pre-trip, during-trip, and post-trip (Minnazi, 2015). The anticipatory phase, the experiential phase and the reflective phase (Jennings, 2006).

Social Media Marketing. Social media is the service that can support collaboration, interaction and communication through discussion, feedback, voting, comments and share information for users. Evans and Mckee (2010) said that «social media marketing is practiced for involving customers at social online whereas the users can feel the natural experience and spending their time». As the comparison, social business focuses on what the consumers say and seeking the creation of communication among consumers with company or community.

Mobile Social Media Marketing In Tourism. The combination of social media and mobile technologies has changed the way people communicate and influence all the steps of travel planning behavior. Especially, the convergence of social media, virtual reality and physical space determines the development pf a new perspective toward mobile social media (MSM) (Minazzi, 2015). The development of mobile devices connected to the Web, along with the convergence of social media, physical space and virtual reality, determines a change of paradigm against Ubiquitous Social Media (USM) (Mandelli and Accoto 2012) or Mobile Social Media (MSM) (Kaplan, 2012; Buhailis and Foerste 2013).

Theory Planned Behavior (TPB). Ajzen (1991, in Jalilvand and Samiei, 2012) Theory of Planned Behavior (TPB) model, described how behavior is formed. According to the TPB, a person can act on the intentions only if they have control over the behavior (Ajzen, 2002). This Theory is not only is intended to explain all habits where people have the ability to exert self control. This theory not only emphasizes the rationality of human behavior, but also on the belief that the target behavior is under the control of the individual consciousness or a behavior not only depends on one's intention to other factors which do not exist under the control of the individual, such as the availability of resources and opportunities to display such behavior (Ajzen, 2002). Based planned Theory of Behavior intention is a function of three determinants, the one that is personal, reflecting both social influence and the third related to the problem of control (Ajzen, 2002).

TPB of tourism and hospitality (Jalilvand and Samiei, 2012). Further, there is one research that integrated an additional variable into TPB model (Cheng et al, 2006). Cheng et al (2006) add variable WOM into TPB model, In this research tries to add a new dimension of e-WOM to TPB model and investigates e-WOM has impact on the TPB relationships especially image destination, attitude toward destination influence travel intention.

Electronic Word of Mouth (e-WOM). A level of online interaction and engagement of people changes also according to how they perceive themselves in relation to others member. Based on Lee et al. (2012), individuals with interdependent self-construct perceive themselves in networking with others and part of larger community. Therefore they are more likely to involved and interact with community members. The sense of belonging among consumer with the consumers and consumers with the community of the active participation in a travel community can increase the action knowledge sharing in social media $(\mathrm{Qu}$ and Lee 2011). Moreover, e-WOM gives the opportunity to people to exert a collective power over companies.

A recent study from Cheung and Lee (2012) found that sense of belonging, enjoyment of helping others, and reputation are the reasons that have a high influence on the customer intention of spreading e-WOM. Finally, a strong reason for creating UGC (User Generated Content) is also to have pleasure and fun interacting with other people (Para-Lopez et al, 2012). Moreover, according to previous research of Gretzel (2008) travelers' income level, 
culture, age, nationality involvement, as well as personality are key factors that influence travelers' social media use and engagement.

Destination Image. In order to successfully in marketing tourism destination, the marketer destination needs to understand the destination image by actual and potential tourist. Destination image as a construct has been defined by Crompton as " ideas and impressions that a person has a destination» (Vaughan, 2007). The image for tourist is very important (Tasci and Gartner, 2007), destination image influences the final choice or behavioral intention (Chen and Tsai, 2007). A collection of specific destination attributes has a profound influence on tourist decision to travel (Loes, 2011), before and after visit including revisit intention.

Gartner (1993, in Nassar et al, 2015) proposed that destination image is composed of three integrated components: Cognitive (How travelers perceive a destination), Affective (how travelers feel about it), Conative or behavioral (how cognitive and affective image influences and predicts traveler's buying behavior). Figure 2.2 shows general framework image destination formation from previous research. According to Baloglu and Mccleary (1999) image was created by stimulus (value, motivation, attitude, age, and education level) and external factor (information source and previous experience).

Attitude Toward Destination. Attitudes, which are relatively permanent and stable evaluative summaries about an item, are an important psychological construct because they have been found to impact and predict many behaviors (Kraus, 1995 in Jalilvand and Samei, 2012). Attitude toward destination emphasize tourist behavior, tourist attitude describes the psychological tendencies expressed by the positive or negative evaluation of tourists when involved in certain behaviors (Ajzen, 1991; Schiffman and Kanuk, 1994; Kraus, 1995 in Jalilvand and Samei 2012). As well as image destination, Tourist's attitude comprised cognitive, affective and behavioral components (Vincent and Thompson, 2002). The cognitive response is the evaluation made in forming an attitude, the effective response is a psychological response expressing the preference of a tourist for an entity and the behavioral component is a verbal indication of the tourist intention to visit. Attitudes predisposes a person to act or perform in a certain manner as shown in studies of household recycling behavior, environmental behavior, and tourism behavior (Jalilvand and Samei, 2012). Tourist attitudes is an effective forecasting of tourist decision for traveling to a certain destination (Jalilvand and Samiei, 2012).

Travel Intention. Behavioral travel intention is a central model and represents the extent of the individual's intentions to perform or not perform one certain behavior (Ajzen, 1991 in Jalilvand and Samiei, 2012). Travel intention represents how a person is willing to adopt a behavior and how much effort he is likely to deploy against that behavior. Behavior in travel intentions are an indication of the readiness to undertake a given behavior and are assumed to precede actual behavior (Zarrad and Debabi, 2015).

For investigating decision making process leading to the choice of travel destination, the theory of planned behavior is often used as a research framework to predict the behavioral intention of choosing a destination (Jalilvand and Samiei, 2012). The central paradigm of the theory of planned behavior is that people are apt to implement particular types of behavior. The specific referents will value and approve of the behavior and that they have necessary resources, abilities, and opportunities to perform such behavior (Ajzen, 1991 in Jalilvand and Samiei, 2012).

\section{CONCEPTUAL FRAMEWORK AND HYPOTHESES}

e-WOM Influence on Destination Image. According to the previous research, it can be made any explanation of the relationship between e-WOM Influence Image Destination. Jalilvand and Samiei (2012) e-WOM has an influence on Destination Image. It supported previous research by Setiawan et al. (2014) that e-WOM has a significant direct effect on destination image. e-WOM is defined as either negative or positive statement made by potential, current and former customer about service or product, which is intentionally made 
to be heard or seen by a lot of people and institution through internet media (Hennig-Thurau et al, 2004).

e-WOM has the influence on destination image,according to in Setiawan et al. (2014) e-WOM affect the destination image because the higher customers share the travel experience through photos on social media will make image destination. It is supported by previous research from Beerlin and Martin (2004, in Jalilvand and Samiei, 2012) concurred that WOM Recommendations from friends and relative were the most truthful and believable communication channel, which also influenced the image of thedestination.

Burgess (1978, in Khairani, 2009) hypothesized that types, quality and quantity from information influence on image, the result from Holbrook (1982) proved that information sources influence on cognitive component from image destination but cognitive component were not influenced by image. Based on previous research, has proven that total of information sources can be used and types of information sources have significance influence on cognitive image destination evaluation for tourist destination (Khairani, 2009).

$\mathrm{H} 1$ : e-WOM has a significant influence on image destination.

e-WOM Influence on Attitude Toward Destination. Attitude toward destination refers to the person's overall evaluation of performing the behavior. Attitude toward destination has been defined as the degree to which a person a favorable or unfavorable evaluation or appraisal of the behavior question, the more favorable the attitude toward destination the stronger will be ab individual's intention to adopt the behavior (Zarrad and Debabi, 2015). According to Zarrad and Debabi (2015) find e-WOM has a significant influence on attitude toward the destination. The research supported by Jalilvand and Samiei (2012), the research finding e-WOM has a significant effect on attitude toward the destination. Pietro and Virgilio (2012) find the e-WOM has a positive significant effect on attitude towards the destination it is supported by social networks, which represent a new source of entertainment by providing some interactive tools for sharing experiences and creating new knowledge topic oriented.

$\mathrm{H} 2$ : e-WOM has a significant influence on attitude toward destination.

e-WOM influence on Travel Intention. e-WOM influence on Travel Intention refers to the person's give a recommendation, comment, and giving appraisal about tourist destination through the internet and social media. It can make the others user on the internet and especially in social media is influenced. In social media such as Instagram, every person have followers and everything post on Instagram will be viewed and read by followers, so that is why e-WOM give a recommendation that influence the others tourist intent to travel.

e-WOM influence on travel intention supported by previous research from Zarrad and Debabi (2015) that e-WOM was positively associated with tourist' future traveling intention towards visiting Tunisia and emphasize the relevance of online user-generated reviews to business performance in tourism. That research refers to Albarq (2013) that e-WOM influence on travel intention to visit Jordan. Jalilvand and Samiei (2012) researched finding that e-WOM impact on travel intention, in that research the antecedents of travel intention in the context of e-WOM on a tourism destination choice is significant because it can help positive destination image and more important to increase tourist's intention to travel. in fact, e-WOM recommendations originated from previous visitors can be taken as the most reliable information sources for potential tourist. Recommendation to the other people in online activities is one of the most important types of information for the tourist interested in traveling.

H3: e-WOM significant influence travel intention.

Destination Image Influence on Travel Intention. Destination image influence on Travel Intention refers to research from Nassar et al (2015) that the importance of effective destination image, travel motivation and cognitive destination image in predicting Kuwaiti traveler behavior, the research finding suggest targeting Kuwaiti nationals with particular strategies that focus on destination image as the largest significant effects on travel intention. Previous research refers to Phau and Quintal et al (2015) that destination image was influenced by consumption value through perceived destination image. It means emotional values in consumption values are significantly influencing the composite vacation destination perception and destination choice intention to Mauritius. 
Research from Phau and Quintal et al (2015) support the research from Mwaura and Acquaye et $\mathrm{Al}$ (2013), the main finding shows image plays an important role in determining whether a destination will be visited or not. The most positive part of their visit was landscaped and authentic nomadic culture cherishes by local people. The psychological image of Mongolia as described by visitor was magnificent, authentic, wild and peaceful. However, destination image of Mongolia has a brand awareness because of Genghis Khan which is often used by Mongolian tour operators to promote Mongolian tourism.

H4: Destination Image Influence on Travel Intention.

Attitude Toward Destination Influence on Travel Intention. Previous research from Jalilvand and Samie et al (2012) has found attitude Toward Destination impact on travel intention. Tourist's positive experience of services, products and other resources provided by tourism destination could lead to repeat visits and to disseminate positive through e-WOM about the destination among tourist. The previous research refers to Pietro and Virgilio (2012) that tourist's attitude towards the use of the social network for archiving information for the destination choice has a strong influence. Hence, being present on social media can play a critical role in attracting new tourist destination and maintaining the existing ones.

H5: Attitude Toward Destination Significant influence on Travel Intention

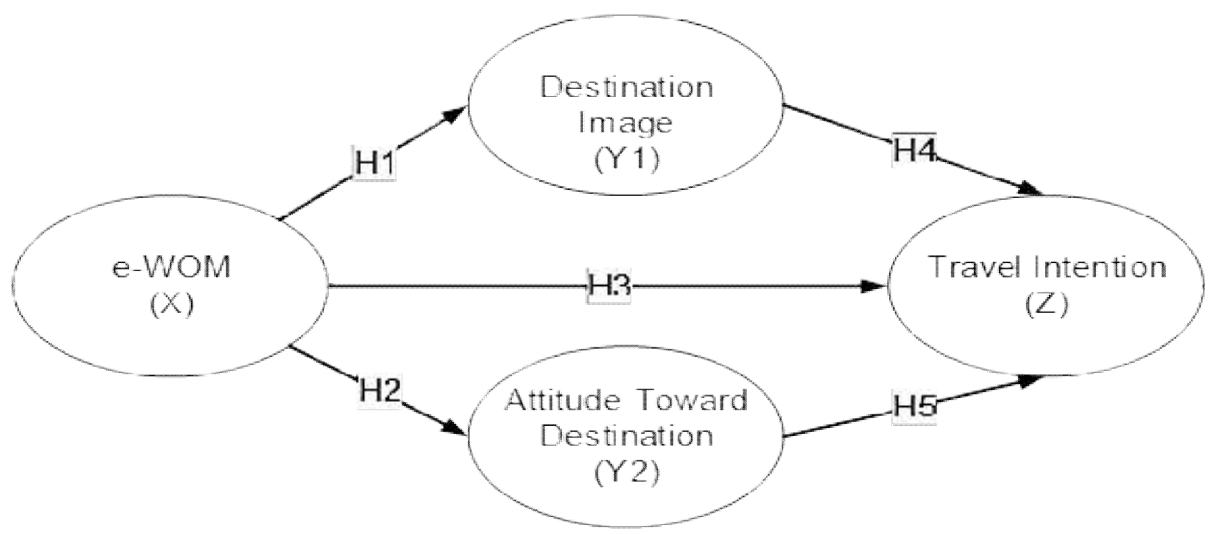

Figure 1 - Hypothesis Model

\section{RESEARCH METHODS}

Instrument Development. The research instruments were developed based on the previous research by an adjustment to fit with the topic being studied. The questions are enclosed in the end of the paper.

Data Collection. The data was collected through survey conducted in Batu City Through Instagramo. The target was the Instagram follower of @explore_batu as online travel reviews. The pilot test with 30 respondent was used to make sure that the questions and wordings were clearly understood by respondents. The total sample when the research was take a place was as many as 13,200 follower. The survey was done in electronic version by using Google docs namely Google form. The questionnaire was sent to @explore_batu and post to Instagram. From total 230 the questionnaire that has been filled is 167 of them can be analyzed. The total valid respondent included 50 males and 117 females. The response range was from 15 to 45 years old, which is mostly coming from undergraduate background and senior high school.

Data Analysis. The present study applies Generalized Structured Components Analysis (GSCA) which is SEM based as recommended has many advantage over other methods (Hwang et al, 2004). GSCA method also can be applied to the complex relationship between variables (can be recursive and not recursive), involves higher-order components (factors) and multi-group comparisons. 
Table 4 - Variable Measurement GeSCA Output

\begin{tabular}{|c|l|c|c|c|}
\hline \multirow{2}{*}{ Variable } & \multicolumn{3}{|c|}{ Weight } \\
\cline { 2 - 5 } & & Estimate & SE & CR \\
\hline \multirow{3}{*}{ e-WOM } & Personal self enhancement & 0.512 & 0.053 & 9.74 \\
\cline { 2 - 5 } & Social benefit & 0.168 & 0.047 & 3.53 \\
\cline { 2 - 5 } & Advice Seeking & 0.266 & 0.046 & $6.49^{\circ}$ \\
\cline { 2 - 5 } & Help other Consumer & 0.089 & 0.041 & $2.17^{*}$ \\
\hline \multirow{2}{*}{ Destination Image } & Cognitive & 0.843 & 0.065 & $12.99^{\circ}$ \\
\cline { 2 - 6 } & Affective & 0.165 & 0.067 & $2.45^{\circ}$ \\
\hline \multirow{3}{*}{ Attitude Towards Destination } & Cognitive & 0.266 & 0.109 & 2.44 \\
\cline { 2 - 6 } & Affective & 0.435 & 0.102 & 4.27 \\
\cline { 2 - 6 } & Behavioral & 0.318 & 0.064 & 5.0 \\
\hline \multirow{2}{*}{ Travel Intention } & Explorative Intention & 0.234 & 0.043 & 5.48 \\
\cline { 2 - 6 } & Preferential Intention & 0.781 & 0.041 & 18.94 \\
\hline
\end{tabular}

$C R^{*}=$ significant at 0,05 level.

\section{RESULTS AND DISCUSSION}

Measurement Model. In measure the results of the study, there will two steps of measurements which is the first was the variable measurement to measure the results of each variable. The results of variable were be shon in table below shows that all of the variable is able to explain the model by the fit criteria and afit criteria that are at least greater than 0.6 which is means that the items in each variable are able to explain the variable for more than $60 \%$ which is the rest is explained by using other items that were not included in this research. The estimated free parameter which meanst that the whole item in each indicator was simply formed by the items stated in this research.

The estimation results from GeSca are shown in figure 2 table 2. According to the results, all the paths among construct are positive and significant at the 0.05 level. The model validity.

The research is empirically tested social commerce construct and bran image throughout the survey. To do this the research performed bootstrapping in the GeSCA software to test the significance of construct path coefficient identified by critical value. The path coefficient was identified in the figure 2. The bootstrapping of 167 sample has shown that e-WOM has a significant influence on travel intention at CR 121.87. Therefore, $\mathrm{H} 1$ is supported. The impact of e-WOM on attitude toward destination is also shows a positive and significant effect at CR 98.33 Therefore, $\mathrm{H} 2$ is supported. Impact of e-WOM on Travel intention is also shows a positive and significant effect at CR 3.48 , therefore $\mathrm{H} 3$ is supported.

The Impact of destination image on travel intention is also shows a positive and significant effect at CR 2.18, therefore $\mathrm{H} 4$ is supported. The impact of attitude toward destination on travel intention is also shows a positive and significant effect at CR 3.62. Therefore, $\mathrm{H} 5$ is supported.

Table 5 - Model Fit of Structural Model (Overall Model)

\begin{tabular}{|c|c|}
\hline \multicolumn{2}{|c|}{ Model Fit } \\
\hline FIT & 0.703 \\
AFIT & 0.700 \\
\hline
\end{tabular}

Table 6 - Structural Model Path Coefficient

\begin{tabular}{|c|c|c|c|c|}
\hline No. & Direct effect & Estimate & SE & CR \\
\hline 1. & e-WOM $(X) \rightarrow$ Destination Image (Y1) & 0.970 & 0.008 & $121.87^{*}$ \\
\hline 2. & e-WOM (X) $\rightarrow$ Attitude Toward Destination (Y2) & 0.962 & 0.010 & $98.33^{*}$ \\
\hline 3. & e-WOM (X) $\rightarrow$ Travel Intention (Y3) & 0.316 & 0.091 & $3.48^{*}$ \\
\hline 4. & Destination Image (Y1) $\rightarrow$ Travel Intention (Y3) & 0.256 & 0.117 & $2.18^{*}$ \\
\hline 5. & Attitude Toward Destination (Y2) $\rightarrow$ Travel Intention (Y3) & 0.410 & 0.113 & $3.62^{*}$ \\
\hline
\end{tabular}

$C R^{*}=$ significant at 0,05 level. 


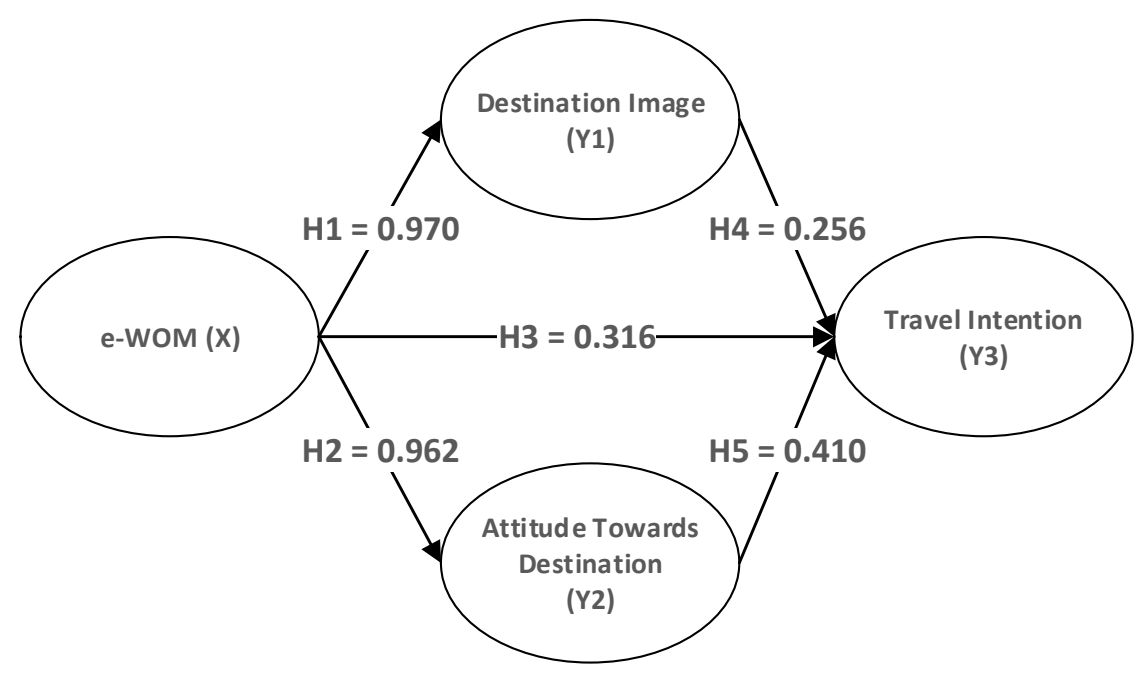

Figure 2 - Hypothesis Testing Results

The indirect effect of e-WOM against travel intention mediated by destination image and attitude toward destination can be seen on table 5 . The indirect effect were indicates that the e-WOM impact on Travel intention mediated by Attitude Towards Destination has shown the larger effect estimated as many as 0.394 at CR 2.19 while the e-WOM on travel intention mediated by destination image shows as many as 0.248 at CR 2.19.

Table 7 - Indirect and Total Effect

\begin{tabular}{|c|c|c|c|c|c|c|c|}
\hline $\begin{array}{c}\text { Independent } \\
\text { Variable }\end{array}$ & $\begin{array}{c}\text { Dependent } \\
\text { Variable }\end{array}$ & $\begin{array}{c}\text { Intervening } \\
\text { Variable }\end{array}$ & $\begin{array}{c}\text { Direct } \\
\text { Coefficient }\end{array}$ & $\begin{array}{c}\text { Indirect } \\
\text { Coefficient }\end{array}$ & SE & CR & Result \\
\hline e-WOM & $\begin{array}{c}\text { Destination } \\
\text { Image }\end{array}$ & - & 0.970 & - & 0.008 & $\begin{array}{c}121.8 \\
7^{*}\end{array}$ & Significant \\
\hline e-WOM & $\begin{array}{c}\text { Attitude } \\
\text { Towards } \\
\text { Destination }\end{array}$ & - & 0.962 & - & 0.010 & 98.33 & Significant \\
\hline e-WOM & $\begin{array}{c}\text { Travel } \\
\text { Intention }\end{array}$ & - & 0.316 & - & 0.091 & $3.48^{*}$ & Significant \\
\hline e-WOM & $\begin{array}{c}\text { Travel } \\
\text { Intention }\end{array}$ & $\begin{array}{c}\text { Destination } \\
\text { Image }\end{array}$ & - & 0.248 & 0.114 & $2.19^{*}$ & Significant \\
\hline e-WOM & $\begin{array}{c}\text { Travel } \\
\text { Intention }\end{array}$ & $\begin{array}{c}\text { Attitude } \\
\text { Towards } \\
\text { Destination }\end{array}$ & - & 0.394 & 0.109 & $3.63^{*}$ & Significant \\
\hline $\begin{array}{c}\text { Destination } \\
\text { Image }\end{array}$ & $\begin{array}{c}\text { Travel } \\
\text { Intention }\end{array}$ & - & 0.256 & - & 0.117 & $2.18^{*}$ & Significant \\
\hline $\begin{array}{c}\text { Attitude } \\
\text { Towards } \\
\text { Destination }\end{array}$ & $\begin{array}{c}\text { Travel } \\
\text { Intention }\end{array}$ & - & 0.410 & - & 0.113 & $3.62^{*}$ & Significant \\
\hline
\end{tabular}

$C R^{*}=$ significant at 0,05 level.

Theoretical and practical contribution. This research was aimed to understand and then describe the impact of e-WOM on Destination Image, Attitude Towards Destination and Travel Intention by using Theory Planned Behavior Approach and social media Instagram. The finding concluded in this research is expected to give a theoretical contribution in social media marketing in tourism and hospitality, particularly the one that related on theory planned behavior on social media Instagram.

The finding was shown that e-WOM on Destination Image is having a greater impact as a direct effect. The research finding was also shown e-WOM on Travel Intention by intervening variable attitude towards destination have a greater indirect effect. Insatgramers tend to believe information sources in e-WOM can influence destination image, attitude toward destination and travel intention, it means social media Instagram can influence Instagramers are willing to visit tourist Destination in Batu City. 
In this research is expected to give any insight to the business, community and government to define marketing strategies parcularly to face social media interaction with the user of Instagram in order to want to visit Batu City as tourist destination. the revolution of social life in digital era is a challenge for the business, community and government to get in touch with tourist who use Instagram. From the finding above it is expected that business practitioners, government and community able to improve e-WOM in Instagram in order to response and facilitate information about a tourist destination and also gaining more potential tourist that are interested with Batu City.

Research limitation and future research. This research is only focusing on one industry which it may be able to be generalized in the total amount of camera and imaging sectors, but it may still has a possibility that the finding could not applied on cross-company or crossindustry sector. The sample involved in this research is relatively in a small amount, so it may limit the generalization of research finding. Since the research is has a timeline during the design to keep the interpretation are stand still with the current situation, the data amount has to be tolerated in a small amount since the online survey is rather difficult to be held than the direct survey (offline), it is suggested to use a larger sample and greater instrument to get a deeper insight in the study on cross company or even cross industry if possible by several adjustment.

\section{CONCLUSION AND SUGGESTIONS}

This research is studying about the impact of e-WOM on destination image, attitude toward destination and travel intention. The framework was coming from the study in the area of theory planned behavior. The results has shown that both direct and indirect mediated by destination image, attitude toward destination has a greater impact against the travel intention. The total effect also shows that e-WOM on attitude toward destination has a greater effect against the travel intention.

The main contribution of this research is that when empirically tested, e-WOM showed that social relationships and interactions of individuals in these platforms, which have emerged in instagram, influence travel intention to visit Batu City. It is also important to note that when the destination image has a lesser effects against travel intention, the online travel community need to enforce its information source against tourist destination knowledge to give a reviews, photo and video by involving Instagramers.

For Business in Tourism Industry such as online travel agent, hotels, and restaurant use social media Instagram to attract youth, women and netizen because in social media Instagram is dominated by them. Online travel agent, hotels and restaurant that have cheap price until medium price can sell their product and services by using Instagram, it is based on the most Instagram users have low income but the market size in Indonesia is very big and potential. By using social media Instagram the business practitioners can give a promotion by involving the customers to promote business by uploading their photos, give a caption, hash tag and tag location in order to attract the others customers.

Government can use Instagram as promotion media by involving youth women and netizen to promote a tourist destination. Government should give a support by making online community to share some tourist destination. Every activities that has a relation with tourism industry, Government should invite the instagramers to promote event management, a new tourist destination and give a price in order to Destination Image in a city or region can increase tourist domestic and foreign to visit.

For Academic, it can be added eithe variable and item about Theory Planned Behavior by using social media approach, not only Instagram but also social network sites such as You Tube and Facebook are the popular social media can spread of electronic word of mouth. The scope of this research just small, the researcher just make a research for Batu City, for future research must can add the wider area of sample by involving either different regional or countries as a comparison. 


\section{REFERENCES}

1. Ajzen, I. 2002. «Perceived Behavioral Control, Self-Efficacy, Locus of Control, and the Theory of Planned Behavior». Journal of Applied Social Psychology, 32(4): 665-683

2. Albarq, Abbas N. 2013. Measuring the Impacts of Online Word of Mouth on Tourist's attitude and intentions to Visit Jordan an Empirical Study. Canadian Center of Science and Education.

3. BPS Kota Batu. 2014. total Tourist Arrival in Batu City. https://batukota.bps.go.id/

4. Baloglu, S., dan McCleary, W.K. 1999. A model of destination image formation. Annals of Tourism Research, Vol. 26, No.4, pp.868-897

5. Buhailis D, Foerste MK. 2013. SoCoMo Marketing for Travel and Tourism. In Information and Communication Technologies in Tourism 2014. Springer International Publishing.

6. Cheng, S. Lam, T. Hsu,C.H.C. 2006. Testing The Sufficiency of The Theory of Planned Behavior: a Case of Customer Dissatisfaction Responses in Restaurants, International Journal of Hospitality Management, Vol.24. No.4.

7. Cheung CM, Lee MK. 2012. What Drives Consumers to Spread Word of Mouth in Online Consumer Opinion Platforms. DecisSupp Syst: 218-225

8. Charo, Sharma «Determining the Impact Of e-Wom On Brand Image And Purchase Intention Through Adoption Of Online Opinions». International Journal Of Humanities And Management Sciences 2015,Vol. 3,Issue 1.

9. Chatterjee, D., Ruj, B. and Mahata, A., 2001. Adsorption and photocatalysis of colour removal from waste water using flyash and sunlight. Catalysis Communications, 2(3-4): 113-117.

10. Chen, C. and Tsai, D. 2007. How Destination Image and Evaluative Factors Affect Behavioral Intentions? Tourism Managament. Vol 28. No.4: pp 1115-1122.

11. Evans D, MCkee J. 2010. Social Media Marketing. Indianapolis: Wiley Publishing.Inc

12. Gretzel U, Yoo KH. 2008. Use and impact of online travel reviews. Inf. Commun Technol Tour. 2: 35-46.

13. Holbrook M.B. 1982. «Hedonic Consumption: Emerging Concepts, Metyhods and Propositions,» Journal of Marketing, Vol. 46, pp. 92-101.

14. Hennig-Thurau T, Gwinner KP, Walsh Gremler DD. 2004. Electronic Word of Mouth Via Consumer Opinion Platforms: What Motivates Consumers to Artucalte Themselves on The Internet? J Interact Mark.

15. Hennig-Thurau et al. 2004. «Electronic Word of Mouth Via Consumer Opinion Platforms: What Motivates Consumers To Artucalte Themselves On The Internet?». Journal Of Intreactive Marketing Volume 18 (1).

16. Hudjiono, A. 2012. Geliat Kota Wisata Batu Periode Krusial Tahun 2007-2012. Kantor Perpusatakaan dan Dokumentasi Pemerintah Kota Batu

17. Jalilvand, Mohammad Reza and Samiei, Neda. 2012. "The Effect of Electronic Word Of Mouth On Brand Image and Pruchase Intention An Empirical Study in The Automobile Industry In Iran». Marketing Intelligence and Planning Vol.30(4): 460-476.

18. Jennings GR. 2006. Perception on Qualtiy Tourism Experience. Elsevier ButterworthOxford: Heinemann.

19. Kertajaya Hermawan and Sapta Nirwandar. 2013. Tourism Marketing 3.0: Turning Tourist to Advocate. PT Gramedia Pustaka Utama: Jakarta.

20. Kotler P, Bowen JT, Makens JC. 2010. Marketing for Hospitality and Tourism, 5th edn. Pearson; Upper Saddle River.

21. Kotler, Philip dan Gery Amstrong. 2010. Prinsip-prinsip Pemasaran. Jilid 1 Edisi 8. Erlangga: Jakarta.

22. Khairani, 2009. Analysis on Variables Affecting the Creation of Tourist Destination Image. Fakultas IImu Sosial dan Politik. Universitas Indonesia.

23. Kaplan AM (2012) If You Love Something, Let It Go Mobile: Mobile Marketing and Mobile Social Media 4x4. Bus Horis. 
24. Laroche, M.C.Kim and L.Zhou. 1996. Brand Familiarity and Confidence as Determinat of Parchase Intention: An Empirical Test In A Multiple Brand Context. Journal of Business Research. 37. 115-120

25. Lee, D., Kim, H.S., and Jiang, HM. 2012. The Role of Self Contrual in Consumers' Electronic Word of Mouth in Social Networking Sites: a Social Cigonitive Approach. Comput Hum Behav.

26. Loes, S. 2011. Destination Image: Origins, Developments and Implications. Pasos. Vol 9 No. 2, pp. 305-315.

27. Mandelli A, Accoto C. 2012. Social Mobile Marketing. Egea: Milano.

28. Mwaura, D. Acqyuaye. D and Jargal, S. 2013. Marketing Implictaions of The Destination Omage of Mongolia. Worldwide Hospitality and Tourism Themes. Vol 5 Iss1 pp 80-91.

29. Nassar, M.A and Mustofa, M.M. and Resinger, Y. 2015. Factor Influencing Travel to Islamic Destinations: An Empirical Analysis of Kuwaiti Nationals. Emerald Insighit. Vol. 9 No.1 pp.36-53.

30. Para-Lopez E, Gutierrez-Tano D, Diaz-armas RJ, Bulchand-Gidumal J. 2012. Travellers 2.0: Motivation, Opportunity and Abillity to Use Social Media. In: Sigala M, Christou E, Gretzel U (eds), Social Media in travel, turism and hospitality. Theory, Practice and Cases. Ashgate, Surrey.

31. Pietro, L.D and Virgilio, F.D. 2012. Social Network for The Choice of Tourist Destination. Attitude

32. Phau, i. Vanessa, Q. amd Tekle, S. 2015. Examining a Consumption Vaues Theory Approach of Young Toursts Towad Destination Choice Intentions. International Journal of Culture, Tourism and Hospitality Research. Emerald Insight. Vol.8. No.2.pp.125-139.

33. Qu, H., Lee, H. 2011. Travelers' Social identification and Membership Behaviors in Online Travel Community. Tour Manage: 1262-1270.

34. Minnazi Roberta,. 2015. Social Media Marketing in Tourism and Hospitality. Springer: University of Insubria Italy.

35. Setiawan, Y.P. Eka A.T, Armanu and Noermijati. 2014. The Effecot of e-WOM on Destination Image, Satisfaction and Loyalty. International Jpirna of Business and Management. Volume 3. pp 22-29.

36. Sorensen, George, dan Jackson, Robert, 2005 Pengantar Studi Hubungan Internasional, Pustaka Pelajar, Yogyakarta,

37. Tasci, A.D.A and Gartner, W.C. 2007. Destination Image and Its Functional Relationships. Journal of Travel Research: 413-25.

38. Vaughan, R.D. 2007. The Images of Romania as a Ptoential Holiday Destination. International Journal of Tourism Policy. Vol.1 No.1: pp.1-6.

39. Vigilia G. 2014. Behavioral Pricing,Online Marketing Behavior and Analytics. Palgrave: New York.

40. Vincent, V. C. and Thompson, W. T. 2002. Assessing Community Support and Sustainability for Ecoturism Development. Journal of Travel Research, 41.153.-160.

41. Wu, Y., and Wang, X. 2011. Preparation and Characterization of Single-Phase $\alpha-$ Fe2O3 Nano-powders by Pechini Sol-gel Method. Materials Letters. 65: pp 2062-2065.

42. Zarrad, $\mathrm{H}$ and Debabi, M. 2015. Analyzing the Effect of Electronic Word of Mouth on Tourists' Attitude Toward Destination and Travel Intention. National Institute of Applied Sciences and Technology, Univeristy of Carthage: Tunisia.

43. Zeithaml, V. Bitner MJ, Gremler DD (2012). Social Commerce Research: An Integrated View. Electron Commer Res Appl. 